http://dx.doi.org/10.4314/jae.v16i2.7

\title{
Effect of Climate Change on Rice Production in Anambra State, Nigeria
}

\author{
H.U. Nwalieji and C. O. Uzuegbunam \\ Phone Number: 07033994751 \\ Address: Department of Agricultural Economics and Extension, Anambra State \\ University, Igbariam campus. \\ E-mail Address: nwaliejihyacinth@yahoo.com
}

\begin{abstract}
The study set out to assess the effect of climate change on rice production in Anambra State, Nigeria. A total sample of hundred (100) respondents was selected using multistage, purposive and simple random sampling techniques. An interview schedule was used to collect data and percentage and mean statistic were used to analyze the data. The mean farming experience and farm size were 17.7 years and 1.63 hectares, respectively; and the major perceived causes of climate change were deforestation, bush burning, excessive use of agro-chemicals in rice production, burning of firewood and farm residues (rice straws \& husks) and natural phenomena among others. The serious negative effects of climate change on rice production were reduction in crop yield and grain quality, destruction of farm land by flood, high incidence of weeds, pests and diseases, surge of infectious human diseases such as meningitis, malaria and cholera, decrease in soil fertility, more flood and droughts in rice fields.
\end{abstract}

\section{Introduction}

Climate change according to Kuta (2011) is one of the most critical challenges ever to face humanity. It can cause the worst forms of economic and security problems for humanity. It determines the health of the resources on which the economy depends and this phenomenon is one of the challenges confronting West Africa among other sub-regions of the world. Climate change however arises from the release of green house gases, carbon dioxide, water vapours and nitrous oxide into the atmosphere due to human activities, such as fossil fuel burning, gas flaring and deforestation (Wikipedia, 2011). Climate change according to World Bank (2010) is expected to hit developing countries the hardest. Its effects-higher temperatures, changes in precipitation patterns, rising sea levels, and more 
frequent weather-related disasters-pose risks for agriculture, food, and water supplies.

The impact of climate change can be vast. According to International Panel on Climate Change (IPCC), (2007) report, climate change and agriculture are interrelated processes, both of which take place on a global scale. Fraser (2008) notes that global warming is projected to have significant impacts on conditions affecting agriculture, including temperature, carbon dioxide, glacial run-off, precipitation and the interaction of these elements. These conditions determine the carrying capacity of the biosphere to produce enough food for the human population and domesticated animals. The overall effect of climate change on agriculture will depend on the balance of these effects and the assessment of the effects of global climate change on agriculture might help to properly anticipate and adapt farming to maximize agricultural production (Fraser, 2008).

In Nigeria, agriculture is the main source of food and employer of labour, employing about 60-70 per cent of the population. It is a significant sector of the economy and the source of raw materials used in the processing industries as well as a source of foreign exchange earning for the country (Mohammed-Lawal and Atte, 2006). Since agriculture in Nigeria is mostly rain-fed, it follows therefore that any change in climate is bound to impact its productivity in particular and other socio-economic activities generally, in the country. The issue of climate change has become more threatening not only to the sustainable development of socioeconomic and agricultural activities of any nation but also to the totality of human existence (Adejuwon, 2004). As further explained by Adejuwon, the effect of climate change implies that the local climate variability which people have previously experienced and adapted to is changing and this change is observed in a relatively great speed.

Local farmers according to Kuta (2011) are seriously concerned about weather variations because of the impact on food security, availability, stability, accessibility and utilization. The change in weather affects livestock, forestry, fishery and the decreases aquatic plant species including rice. Production of rice, which is the world's most important crop for ensuring food security and addressing poverty, will be thwarted as temperatures increase in rice-growing areas with continued climate change (Gumm, 2010).

Ramirez (2010) notes that unforeseen changes associated with global warming in temperature, carbon dioxide and rainfall are expected to impact rice production. Studies have shown that increase in temperature, due to climate change, adversely affect rice crop physiology ultimately decreasing crop yield and grain quality. Gumm (2010) re-affirms that rising temperature during the past 25 years have already cut rice yield growth rate by 10-20 percent in several locations. He further adds that unless there is a change in the rice production methods or new rice strains that can withstand higher temperatures, are developed, there will be a loss in rice production over the next few decades as days get hotter. 
Rice production is one of the major primary sources of cash income for farmers in Anambra state. Rice is produced under upland, swamp and irrigated lowland conditions, mainly by small holder farmers with one or two hectare holdings (Nwalieji, 1999). National Cereals Research Institute, NCRI (2004) identified the constraints that limit rice production efforts by farmers to include problems associated with research, poor pests and disease management, low soil fertility, use of simple and inadequate farm implements, low institutional and infrastructural support, lack of credit facilities, inadequate improved input delivery, lack of appropriate marketing channels, inadequate irrigation facilities and poor extension services. The major problems associated with rice production according to Ajatomobi, Abiodun and Hassan (2010) include drought, flooding, salt stress and extreme temperatures, all of which are expected to worsen with climate change. Drastic changes in rainfall patterns and rise in temperatures will introduce unfavourable growing conditions into the cropping calendars thereby modifying growing seasons which could subsequently reduce productivity. From the foregoing, there is clear evidence in parts of the rice growing regions of Anambra State, Nigeria that rice production is already suffering considerable setback due to climate change. This assertion informs the need to carry out a study to examine the effect of these drastic changes on rice production in Anambra State of Nigeria.

\section{Objectives of the Study}

The main objective of the study was to assess the effect of climate change on rice production in Anambra State, Nigeria. Specifically, the objectives were to:

1. ascertain respondents' perceived causes of climate change; and

2. identify respondents' perceived effect of climate change on rice production.

\section{Methodology}

The study was conducted in Anambra State of Nigeria. The state has four Agricultural Zones (AZs) - Aguata, Anambra, Awka and Onitsha. There are 6 blocks in Aguata AZ, 4 blocks in Anambra AZ, 5 blocks in Awka AZ and 6 blocks in Onitsha AZ. The soil types of the area are suitable for growing many varieties of crops. The vegetation is generally rainforest. However some parts consist of wooded savanna.

The population of the study consisted of all the rice farmers in the $4 \mathrm{AZs}$ of Anambra State. Multistage sampling technique was applied in the selection. The first stage involved purposive selection of Anambra zone out of the $4 \mathrm{AZs}$ in the State because of the high rate of rice production in the area. Second stage involved purposive selection of two blocks (Anambra East and Ayamelum) out of the 4 blocks due to the same reason. Third stage was also the purposive selection of three most active rice producing circles/communities (Omor, umumbo, and Ifite- 
Ogwari) from Ayamelum block and two circles (Enugu-Otu and Eziagulu-Otu) from Anambra East block, giving a total number of five circles/ communities selected. Stage four involved selection of twenty rice farmers from each circle/community using simple random sampling technique. This gives a total sample of hundred (100) respondents. An interview schedule was used to collect data for the study. The interview schedule consists of structured

The socio-economic characteristics of the respondents were measured as follows: Age (years), 20-29, 30-39, 40-49, etc; Gender (male or female); Marital Status (single, married, widowed/divorce); Level of Education ( no formal education, primary, secondary, Tertiary); Household size, 1-5, 6-10, 11-15, etc; Farming experience (years), 1-5, 6-10, 11-15, 16-20, etc; Farm size (hectares), 0.1-1.0, 1.1-2.0, 2.1-3.0, etc. Objective 1: The respondents were asked to indicate on a 4point likert type scale the extent of their perceptions towards the shortlisted causes of climate change. Their response categories and the corresponding weighted values were: To great extent $=4$, to some extent $=3$, to little extent $=2$, and to no extent $=1$. These values were added to obtain a value of 10 which when divided by 4 gives a mean score of 2.5. The respondents mean were obtained on each of the items. Any mean score greater than or equal to 2.5 was regarded as "to great extent", while any mean score less than 2.5 was regarded as "to no extent". Objective 2: The respondents were asked to indicate on a 4-point likert type scale the perceived effect of climate change on rice production. Their response categories and the corresponding weighted values were: very serious $=4$, serious $=3$, somewhat serious $=2$ and not serious $=1$. Any mean score greater than or equal to 2.5 was regarded as the effect being serious, while any mean score less than 2.5 was regarded as "not serious". Data collected on socio-economic characteristics was presented using percentage and mean score, while objectives 1 and 2 were analyzed using mean statistic.

\section{Results and Discussion}

\section{Socio-economic characteristics of the respondents}

Table 1 shows that majority (48.0\%) of the respondents were between the age range of 40 to 49 years. This was followed by $24.0 \%$ and $16.0 \%$ of them whose ages range from 50 to 59 years and 30 to 39 years respectively while the remaining (12.0\%) were between the age ranges of 60 to 69 years. The mean age of the respondents was 47.7 years. This implies that majority of the respondents are still within their middle, active and productive ages and hence can engage efficiently in rice production. This corroborates the findings of Nwalieji (1999) that ninety five percent of middle aged farmers were involved in rice production. Data in Table 2 show that majority (66.0\%) of the respondents were males while the remaining $(34.0 \%)$ were females. The result implies that rice production in the study area was dominated by males.

Table 1 also reveals that majority $(70.0 \%)$ of the respondents were married while $6.0 \%, 20.0 \%$ and $4.0 \%$ were single, widowed and divorced respectively. The 
implication is that rice farmers had tendency to engage helping hands through marriage to provide family labour required for rice farming. Entries in table 1 show that majority $(56.0 \%)$ of the respondents had household size between 6-10 persons while $36.0 \%$ and $8.0 \%$ had between $1-5$ and $11-15$ persons respectively. The mean household size was about 7 persons. This implies that the respondents had relatively large family sizes which could provide cheaper source of farm labour. Table 1 indicates that a greater proportion (44.0\%) of the respondents attended primary school while $20.0 \%$ and $6.0 \%$ completed secondary school and attended tertiary institution respectively, $30.0 \%$ had no formal education. This shows that about $70.0 \%$ of the rice farmers were literate and possess significant educational experience that can be useful in the study of climate change and their adaptation strategies. Also, it had been established that the educational level of farmers determine their adoption behavior to a large extent (Obinne, 1991).

Table 1 shows that majority ((36.0\%) of the respondents had engaged in rice farming activities for a period of $11-20$ years while $28.0 \%, 22.0 \%$, and $14.0 \%$ had been into rice farming for 1-10years, 21-30 years and 31-40 years respectively. The mean (M) rice farming experience was 17.70 years. This means that the rice farmers had been farming for a fairly long period of time. This long experience would enable them observe changes and variability in the pattern of climate which according to IPCC (2007) should be for at least a period of one decade.

Data in Tale 1 reveal that majority $(40.0 \%)$ of the respondents had farm land between 1.1-2.0 hectares while $34.0 \%, 14.0 \%, 8.0 \%$ and $4.0 \%$ owned between 0.1-1.0 hectares, 2.1-3.0 hectares, 3.1-4.0 hectares and 4.1-5.0 hectares respectively. The mean $(\mathrm{M})$ farm size was 1.63 hectares. This shows that the respondents were predominantly small- scale farmers. This is in agreement with Nwalieji (1999) who stated that rice is produced under uplands, swamps and irrigated lowlands and is dominated by small holder farmers who cultivate small hectares of land between one to two hectares. Table 1 also shows that majority $(92.0 \%)$ of the respondents engage in rainy season production of rice while $3.0 \%$ and $5.0 \%$ grow rice during dry season and both rainy and dry seasons respectively. This implies that natural disasters such as flooding due to heavy rainfall could be a threat to rice production in the area, as paddies may be washed away or plants lodge into heavy floods. 


\section{TABLE 1}

Percentage distribution of respondents according to socio-economic characteristics $(n=100)$

\begin{tabular}{|c|c|c|}
\hline \multirow{2}{*}{\multicolumn{3}{|c|}{$\begin{array}{l}\text { Socio-economic variables } \\
\text { Aqe (vear) }\end{array}$}} \\
\hline & & \\
\hline $30-39$ & 16.0 & \\
\hline $40-49$ & 48.0 & 47.70 \\
\hline $50-59$ & 24.0 & \\
\hline 60 and above & 12.0 & \\
\hline \multicolumn{3}{|l|}{ Gender } \\
\hline Male & 66.0 & \\
\hline Female & 34.0 & \\
\hline \multicolumn{3}{|l|}{ Marital status } \\
\hline Single & 6.0 & \\
\hline Married & 70.0 & \\
\hline Widowed & 20.0 & \\
\hline Divorced & 4.0 & \\
\hline \multicolumn{3}{|l|}{ Educational qualification } \\
\hline No formal education & 30.0 & \\
\hline Primary education & 44.0 & \\
\hline Secondary education & 20.0 & \\
\hline Tertiary education & 6.0 & \\
\hline \multicolumn{3}{|l|}{ Household size } \\
\hline $1-5$ & 36.0 & \\
\hline $6-10$ & 56.0 & 6.60 \\
\hline $11-15$ & 8.0 & \\
\hline \multicolumn{3}{|l|}{ Rice farming experience } \\
\hline (years) & 28.0 & \\
\hline $1-10$ & 36.0 & 17.70 \\
\hline $11-20$ & 22.0 & \\
\hline $21-30$ & 14.0 & \\
\hline \multicolumn{3}{|l|}{$31-40$} \\
\hline Farm size (hectares) & 34.0 & \\
\hline $0.1-1.0$ & 40.0 & \\
\hline $1.1-2.0$ & 14.0 & 1.63 \\
\hline $2.1-3.0$ & 8.0 & \\
\hline $3.1-4.0$ & 4.0 & \\
\hline \multicolumn{3}{|l|}{$4.1-5.0$} \\
\hline Season of cropping & 92.0 & \\
\hline Rainy season & 3.0 & \\
\hline Dry season & 5.0 & \\
\hline Dry and rainy seasons & & \\
\hline
\end{tabular}

Field survey, 2011 


\section{Causes of Climate Change}

Table 3 shows that the respondents perceived deforestation $(M=2.90)$, bush burning ( $M=2.52)$, gases released from industries $(M=2.40)$, use of excessive chemicals in rice production ( $M=2.70)$, application of excess nitrogenous fertilizers $(M=3.50)$, natural phenomena $(M=3.72)$, violation of local custom $(M=2.66)$ and burning of firewood and farm residues (rice straws \& husks) $(M=2.65)$ caused adverse climate change to great extent. Other causes of climate change such as overgrazing, burning of fossil fuels, depletion of ozone layer, crude oil spillage, indiscriminate use of electric generators to generate energy, slash and burn practice, changes in land use and $\mathrm{CO} 2$ emissions from transportation, with low mean (M) scores of 1.24, 1.10, 1.08, 1.50, 1.50, 2.20, 1.74 and 1.95 respectively, did not cause climate change (perceived as to no extent).

TABLE 2

Distribution of respondents according to perceived causes of climate change

\begin{tabular}{lll}
\hline Causes of climate change & $\begin{array}{l}\text { Mean } \\
\text { (M) }\end{array}$ & SD \\
\hline Deforestation & $2.90^{*}$ & 0.50 \\
Bush burning & $2.52^{*}$ & 0.54 \\
Overgrazing & 1.24 & 0.79 \\
Burning of fossil fuels & 1.10 & 0.82 \\
Gases released from industries & $2.40^{*}$ & 0.55 \\
Use of excessive chemicals in rice production & $2.70^{*}$ & 0.52 \\
Application of excess nitrogenous fertilizers & $3.50^{*}$ & 0.46 \\
Depletion of ozone layer & 1.08 & 0.83 \\
Natural phenomena & $3.72^{*}$ & 0.41 \\
Crude oil spillage & 1.50 & 0.72 \\
Violation of local custom & $2.66^{*}$ & 0.53 \\
Indiscriminate use of generators to generate energy & 1.50 & 0.72 \\
Slash and burn agriculture & 2.20 & 0.60 \\
Burning of firewood and farm residues (rice straws \& husks) & $2.65^{\star}$ & 0.53 \\
Changes in land use & 1.74 & 0.68 \\
CO $_{2}$ emissions from transportation & 1.95 & 0.61 \\
\end{tabular}

${ }^{*}=$ To great extent $(M \geq 2.50)$ 


\section{Negative Effect of Climate Change on Rice Production}

Table 4 shows that the respondents agreed that climate change had serious negative effects on rice production. The factors that experienced "serious effects" were: reduction in crop yield $(M=3.85)$, reduction in grain quality $(M=2.62)$, destruction of farm land by flood $(M=2.56)$, food unavailability, instability, inaccessibility and poor utilization $(\mathrm{M}=2.55)$, incident of pests and diseases $(M=2.72)$, surge of infectious diseases such as malaria, cholera on farmers $(M=2.62)$, decrease in soil fertility $(M=2.90)$, incidence of droughts in rice field $(M=2.83)$ and high incidence of weed $(M=2.60)$. The effect of climate change was said not to be serious on the items with low mean scores. These included loss of crops due to flood, loss of income, higher food prices, aggravation of rural poverty, soil erosion, high winds, change in production calendar and excessive rainfall with mean (M) scores of 1.95, 2.20, 1.60, 2.00, 1.72, 1.34, 2.05 and 2.35 respectively. 
TABLE 3

Distribution of respondents according to perceived negative effect of climate change on rice production

\begin{tabular}{ll}
\hline Effect of climate change & Mean $(\mathrm{M})$ \\
\hline Reduction in crop yields & $3.85^{\star}$ \\
Reduction in grain quality & 0.46 \\
Loss of crops due to flood & $2.62^{\star}$ \\
Destruction of farm lands by flood & 0.56 \\
Loss of income & 1.95 \\
Food unavailability, instability ,inaccessibility and poor & 0.76 \\
utilization & $2.56^{\star}$ \\
Incident of pests and diseases & 0.59 \\
Surge of infectious disease such as malaria, cholera on & 2.20 \\
farmers & 0.67 \\
Higher food prices & $2.55^{\star}$ \\
Aggravation of rural poverty & 0.59 \\
Decrease in soil fertility & $2.72^{\star}$ \\
Soil erosion & 0.53 \\
Incidence of droughts in rice field & $2.62^{\star}$ \\
High winds & 0.56 \\
High incidence of weed & 1.60 \\
Change in production calendar & 0.83 \\
Excessive rainfall & 2.00 \\
& 0.75 \\
& $2.90^{\star}$ \\
& 0.52 \\
& 1.72 \\
& 0.80 \\
\hline
\end{tabular}

${ }^{*}=$ Serious effect $(M \geq 2.5)$ 


\section{Conclusion and Recommendations}

The socio-economic characteristics of the respondents indicated that majority were males; they were at their middle ages; they have large household size and long year of farming experience. The major causes of climate change in the study area were deforestation, bush burning, gases released from industries, excessive use of chemicals in rice production, application of excess nitrogenous fertilizers, and other natural phenomena. The serious negative effects of climate change on rice production in the study area were, reduction in crop yield and grain quality, destruction of farm land by flood, food unavailability, instability, inaccessibility and poor utilization, incidence of pests and diseases, surge of infectious diseases such as malaria, cholera on farmers, decrease in soil fertility, incidence of droughts in rice field and high incidence of weed. Based on the findings above, the following recommendations were made: 1 . Efforts should be geared toward cushioning the effect of climate change on rice production by the stakeholders such as the government, extension agencies, research institutions, climatological /metrological institutes, disaster management agencies, higher institutions, local farmers and other stakeholders. 2. There should be provision of good irrigation facilities, improved rice varieties, etc. to the rural farmers in order to mitigate the effect of climate change for optimum rice production in the area. In this connection, it must be noted that potentials still abound in parts of Anambra State for the construction of minor irrigation schemes to supply all-season water to low-lying flood plains where rice is grown. This was a feature of the mid-sixties. It is recommended that government and NGOs should reactivate this practice to mitigate the negative effects of climate change. 3. Human activities causing climate change such as deforestation among others should be discouraged. 


\section{References}

Adejuwon, S.A. (2004). Impact of climate variability and climate change on crop yield in Nigeria. Contributed paper to Stakeholders workshop on Assessment of Impact and Adaptation to Climate Change (AIACC): 2-8

Ajetomobi, J., Abiodun, A., and Hassan, R. (2010). Economic impacts of climate change on rice agriculture in Nigeria. Tropical and Subtropical Agroecosystems, 14(2011): 613-622.

Fraser, E. (2008). "Crop yield climate change." Retrieved on September 20 ${ }^{\text {th }}, 2011$ from http://en.wikipedia.org/wiki/climate-change-and-agriculture

Gumm, Daniel (2010). Nigeria: Climate change to affect rice yields. Vanguard, Agust19. Retrieved on September $20^{\text {th }}, 2011$ from http://allafrica.com/nigeria/climate...

International Panel on Climate Change, (IPCC). (2007). Climate change 2007: Impacts, adaptation and vulnerability: Contribution of Working Group II to the Fourth Assessment report of the IPCC. Cambridge UK: Cambridge University Press

Kuta, D. A. (2011). Nigeria: Climate change and agriculture in country. Leadership (Abuja), September 18. Retrieved on September 20 2011 from http://allafrica.com/nigeria/climate...

Mohammed-Lawal, A. and Atte ,O.A (2006). An analysis of agricultural production in Nigeria. African Journalof General Agriculture 2(1):1-6

National Cereal Research Institute (NCRI) (2004). Training manual on rice production produced for the Presidential Initiative on Paddy Production for Abakiliki and Omor Rice mills and other rice processors in south east zone of Nigeria held at Umudike, Abia State. Pp.1-128

Nwalieji, H. U. (1999). The impact of lower Anambra irrigation project (LAIP) on improved rice production in Ayamelum LGA of Anambra state, Nigeria. B. Agric. project, dept. of Agricultural Extension, UNN.

Obinne, C. P. (1991). Adoption of improve cassava production technologies by small-scale farmers in Bendel State. Journal of Agriculture, Science and Technology, 1(1): 12-15

Ramirez, A. (2010). The impact of climate change on rice production. Retrieved on September $20^{\text {th }}, 2011$ from http://allafrica.com/nigeria/climate...

Wikipedia (2011). Climate change and agriculture. Retrieved on September $20^{\text {th }}$, 2011 from http://en.wikipedia.org/wiki/climate-change-and-agriculture.

World Bank (2010). Climate change and World Bank. Retrieved on $20^{\text {th }}$ September from http://www.worldbank.org. 